\title{
Cecily Mackworth, Une amitié de Mallarmé: Ernest Chatelain
}

Isabella Giovinazzo

\section{(2) OpenEdition}

Journals

Edizione digitale

URL: https://journals.openedition.org/studifrancesi/38076

DOI: 10.4000/studifrancesi.38076

ISSN: 2421-5856

Editore

Rosenberg \& Sellier

\section{Edizione cartacea}

Data di pubblicazione: 15 décembre 2004

Paginazione: 637

ISSN: 0039-2944

\section{Notizia bibliografica digitale}

Isabella Giovinazzo, «Cecily Mackworth, Une amitié de Mallarmé: Ernest Chatelain», Studi Francesi

[Online], 144 (XLVIII | III) | 2004, online dal 30 novembre 2015, consultato il 08 mai 2021. URL: http:// journals.openedition.org/studifrancesi/38076 ; DOI: https://doi.org/10.4000/studifrancesi.38076

Questo documento è stato generato automaticamente il 8 mai 2021.

\section{(c) $(1) \&$}

Studi Francesi è distribuita con Licenza Creative Commons Attribuzione - Non commerciale - Non opere derivate 4.0 Internazionale. 


\title{
Cecily Mackworth, Une amitié de Mallarmé: Ernest Chatelain
}

\author{
Isabella Giovinazzo
}

\section{NOTIZIA}

CECILY MACKWORTH, Une amitié de Mallarmé: Ernest Chatelain, «Histoires Littéraires», 2003

no. 15 , pp. 53-63.

1 L'articolo illustra la singolare amicizia tra Mallarmé e Chatelain, pubblicista e poeta di scarso talento, espatriato in Inghilterra e naturalizzato inglese dal 1848, il cui primo incontro risale al 1862, in occasione del primo soggiorno di Mallarmé a Londra. Tale amicizia, singolare alla luce delle differenze personali oltre che letterarie tra il poeta amante della tranquillità, che sogna «la musique du Silence» e il «mauvais poète» dal carattere rude e aspro, e più anziano di oltre quarant'anni, si protrae fino alla morte del più anziano, come dimostrano gli scambi epistolari, ed è interessante dal punto di vista letterario perché dimostra in Mallarmé, sicuramente consapevole del suo talento poetico, la disponibilità ad accogliere oltre che i versi di discutibile valore prodotti da Chatelain, anche la sua mediazione nell'ambito della conoscenza della lingua e della letteratura inglese. 